\title{
Public Private Partnerships and the Public Interest: A Case Study of Ottawa's Lansdowne Park Development
}

\section{Tamara Krawchenko \& Christopher Stoney}

\author{
Carleton University
}

\begin{abstract}
Public private partnerships (PPPs) are increasingly advocated as beneficial for the delivery of public services, facilities, and infrastructure for municipal governments. However, such partnerships often raise serious concerns about transparency and accountability. While municipal governments across Canada have tried to increase public participation in local affairs, PPPs can impede such efforts. This article presents a case study of the Lansdowne Park PPP redevelopment in the City of Ottawa. We focus on how transparency and citizen engagement have been compromised and circumvented and link to broader issues of how to balance the privileged status of business and the demands for commercial confidentiality with the public interest, transparency, and citizen engagement in projects that use PPPs. The article concludes by arguing that some projects and some conditions can render the use of PPPs inappropriate and counterproductive in terms of both effectiveness and the basic principles of good governance.

\section{RÉSUMÉ}

Les partenariats public-privé (PPP) sont de plus en plus préconisés par les municipalités comme étant une solution avantageuse pour la prestation de services publics ainsi que la réalisation de projets d'installations et d'infrastructures publiques. Toutefois, de tels partenariats soulèvent souvent d'importantes préoccupations quant à la transparence et la reddition de compte en lien avec ce processus. Plusieurs municipalités canadiennes ont fait de grands progrès pour accroître la participation des citoyens aux affaires municipales, mais les PPP peuvent représenter un obstacle important à de tels efforts. Cet article présente une étude de cas sur le réaménagement du parc Lansdowne dans le cadre d'un PPP à la Ville d'Ottawa. L'article se concentre sur la façon dont la transparence et l'engagement des citoyens ont été compromis et contournés dans ce processus. Cette analyse est liée à des considérations sur la façon d'atteindre un équilibre entre le statut privilégié de l'entreprise et les exigences de confidentialité des informations commerciales avec l'intérêt public, la transparence et l'engagement des citoyens dans des projets qui utilisent des PPP. L'article conclut en affirmant que certains projets et certaines conditions peuvent rendre certains PPP inappropriés et contre-productifs en ce qui a trait à l'efficacité et aux principes fondamentaux de bonne gouvernance.
\end{abstract}

\section{Keywords / Mots clés}

Public private partnerships; City of Ottawa; Public engagement; Transparency; Accountability; Good governance; Municipal government / Partenariats public-privé; Ville d'Ottawa; Engagement public; Transparence; Reddition de compte; Municipalités 


\section{Krawchenko and Stoney (2011)}

\section{INTRODUCTION}

There is a trend toward the increased use of public private partnerships (PPPs) both in Canada and across OECD countries (OECD, 2010, p. 11). Federally, the Canadian government has taken a leadership role in the development of and advocacy for PPPs through the creation of Public Private Partnerships Canada (est. 2008) and by linking funding eligibility for some programs to the consideration of PPPs. ${ }^{1}$ Many provincial governments have increased their support for PPPs by creating provincial Crown corporations to promote and fund them, ${ }^{2}$ and the trend is also evident at the municipal level, signifying the increasing institutionalization of PPPs as a service and infrastructure delivery mechanism. PPP requirements for competitive and confidential procurement processes as well as long-term closed contracts often place the PPP processes, and the goals of good governance and public accountability, at odds with one another (Acar, Chao, \& Kaifeng, 2008; Brinkerhoff \& Brinkerhoff, 2011; Johnston \& Gudergan, 2007; Macário, 2010; Miraftab, 2004; Ortiz \& Buxbaum, 2008). This is particularly significant at the local level where there is less experience with PPP adoption. Our study examines these issues through a case study of the City of Ottawa's most recent public private partnership: the Lansdowne Park redevelopment.

The Lansdowne Park redevelopment is an infrastructure PPP. It has been chosen to highlight how the processes of institutionalization surrounding PPPs are being realized at the local level. The case made provincial and national headlines when citizens' groups brought legal challenges against it after more than three years of disputes. While our case study focuses on only one PPP, it illustrates the fundamental tension between inscrutable elements of corporate-style decision-making and the public's perceived "right to know." In the words of Tindal and Tindal, "[p]rivate companies operate with a degree of confidentiality and secrecy not easily reconciled with the openness and public accountability values (and, often, legal requirements associated with municipal operations)" (2009, p. 291). Our intention in using the Lansdowne Park case is not to be drawn into questions of unlawfulness at the centre of the court challenge, or to argue that PPPs should never be used, but to highlight the governance issues and policy decisions that have resulted in such a struggle between a municipality and some of its citizens. In so doing we identify a number of conditions that render the use of PPPs inappropriate and counterproductive in terms of effectiveness, risk, and the basic principles of good governance. Conversely, we also argue that under certain conditions, the need for transparency, citizen engagement, and due process may outweigh the potential benefits of PPPs.

While many cities have made great strides in increasing the amount of public participation and citizen engagement in planning processes, high-stakes development projects, particularly those involving PPPs, tend to circumvent these goals by limiting the information available to and engagement with the public. Consequently, public participation tends to be restricted to the perfunctory processes that Arnstien (1969) regarded as "therapeutic" and "manipulative." For some PPP developments such as roads and sewers, the public's need for information and participation may be relatively limited. However, for controversial and highly political projects, such as the redevelopment of Lansdowne Park, such engagement practices may be seen as entirely inadequate for the task of governing democratically. The Lansdowne case also raises the question of why PPP frameworks in Ottawa and other municipalities remain underdeveloped with respect to protecting the public interest. We consider the implications of this as well as the types of safeguards that are required.

As the increasing institutionalization of PPPs in Canada leads them toward becoming a favoured method of financing, procurement, and operations, their role within the broader framework of governance and accountability will also need to be addressed, particularly for projects that demand elevated levels of public scrutiny and participation. Otherwise, the political and democratic costs of PPPs will not be fully captured or addressed, thereby adding to the so-called "democratic deficit" and fuelling calls for clarification of the policies 


\section{Krawchenko and Stoney (2011)}

regulations and laws that are supposed to protect communities and promote the public interest. In a review of the literature on PPPs we found that the literature on the categorization, adoption, and implementation of PPPs from a technical standpoint (e.g., European PPP Expertise Centre, 2011) and the literature that focuses on value for money ${ }^{3}$ and efficiency claims (Bel \& Warner, 2008; Boyne, 1998; Eggers \& O'Leary, 1995; Entwistle \& Martin, 2005; Warner \& Hefetz, 2004; OECD, 2009, 2010; Savas, 2000) tend to engage little with the PPP literature on citizen engagement, transparency and accountability (e.g., Bardach, 2003; Bradford, 2003; Forrer, Kee, Newcomer, \& Boyer, 2010; Graham \& Philips, 2008; Ilcan, 2009; Siemiatycki, 2010; Wallner, 2008). Our aim is to increase the dialogue between these literatures and to make the case that public engagement should not be treated as a separate issue from the technical literature on PPP adoption.

The article begins by examining the major themes that emerge in analyses of PPPs-the rationales for their adoption, increasing complexity, and accountability, and the role of the public sector. It then introduces Ottawa's most recent and controversial foray into PPPs-the Lansdowne Partnership Plan (LPP). Finally, some conclusions are drawn regarding how to incorporate and apply the principles of "good governance" to the PPP process. This is particularly significant given the well-observed trend to conflate public and private roles to the point where "good governance at the municipal level is now largely defined by the ability of formal government to assist (Harvey, 1989; Leitner, 1990), collaborate with (Elkin, 1987; Stone, 1989), or function like (Box, 1999) the corporate community" (cited by Hackworth, 2007, p. 11).

This article uses historical institutionalism to guide the research, paying attention to politics, context, history, and the processes of institutionalization. Our evidence is drawn from a mixed methodology combining participant observation at meetings/events related to Lansdowne with a literature review, primary document analysis (e.g., acts, regulations, policy statements, and legal documentation) and a review of the grey literature/media. ${ }^{4}$ The literature review informs the rationale for and implications of the adoption of PPPs, and PPP theory is then contrasted with actual practice through a review of the Lansdowne case. We have analyzed primary documents to map the institutional and regulatory environment for PPPs across Canada, including at the local scale, thereby contextualizing the City of Ottawa's engagement with these practices. Attendance at Lansdowne-related meetings/events was used to gauge public engagement practices, and a media analysis using LexisNexis database search was used to analyze major debates. Throughout, we pay close attention to the divergence between formal rules and practices and more informal modes of adoption. Through our case study of Ottawa we see a divergence between PPP policy and practice. A lesson from historical institutionalism is that institutions can become path dependant. We hope that, at this relatively early stage of PPP adoption, local governments like Ottawa will strengthen the institutions (rules, policies, guidelines, practices) used to develop them. The alternative is to see perverse outcomes and lengthy court cases as per the Lansdowne case.

\section{PPPs: Rationales, complexity, and accountability}

PPPs emerged from a climate of fiscal austerity in the 1990s when governments became increasingly interested in leveraging private finance, particularly for large infrastructure projects. Symbolizing the so-called "neo-liberal turn," PPPs emerged from an ideological orientation for smaller government and the pro-privatization pressures of the 1970s and 1980s coupled with pressures of deregulation, smaller government, and the outsourcing and privatization of infrastructure and services (Loxley \& Loxley 2010). In the late 1980s and 1990s, PPPs spearheaded experimentation with alternative service delivery and became an important tool in the implementation of New Public Management (NPM) practices (Hood, 1995).

NPM's focus on partnership engagement, specifically with the private sector, has been a driving force of the PPP model. As Hackworth explains: 


\section{Krawchenko and Stoney (2011)}

One of the foundations of neoliberal governance at the local level is public-private cooperation. These alliances can vary considerably in form but city governments are increasingly expected to serve as market facilitators, rather than salves for market failure. Cities have moved from a managerial role under Keynesianism to an entrepreneurial one under neoliberalism. No longer are cities as able to establish regulatory barriers to capital; on the contrary, they are expected to lower such barriers ... to behave as businesses themselves. (Harvey, 1989 cited in Hackworth, 2007, p. 61)

It has also ushered in a treatment of citizens as clients or customers - a connotation that is largely at odds with that of public/citizen engagement. Historically, PPPs can and should be seen as part of an ongoing struggle to reform local government in ways that exclude certain groups and interests from the decision-making process and at the same time privilege their own status and influence over policies and outcomes that help shape cities, growth, and development (Plunkett \& Betts, 1978). As Tindal and Tindal contend, "[The] reformers were interested in restoring the efficiency and effectiveness of municipal service delivery but, at the same time they were plainly concerned with restricting the influence of the cities' burgeoning population of working people upon the conduct of municipal affairs" (2009, p. 11).

After more than a century of continued struggle over the role of municipal governments, PPPs bring these concerns back into sharp focus, reinforcing and institutionalizing the dominant role of private capital and the marginalized influence of other local interests within the community. To examine this in more depth, this section will examine three major themes that emerge in analysis of PPPs: 1) the basic rationales for their adoption; 2) their level of complexity; and 3) the implications for this on transparency, accountability, and the role of the public sector.

PPPs differ from traditional procurement mechanisms in several important ways. Whereas contractors under traditional procurement are unbundled multiple firms, under PPPs they are a bundled consortia where ownership is private (as opposed to public in the case of traditional procurement). PPPs are often adopted at a much earlier stage of the project development than in traditional procurement, and thereby have greater influence over the scope and form of a project. PPPs can differ significantly in scope and function. However, as the name implies, they involve public sector partnership with a private party wherein the private sector assumes substantial financial, technical, and operational risk in the project as opposed to traditional procurement where the risk is more public. The OECD argues that PPPs (as an ideal type) should reflect equally shared risk by both the private and public partners (OECD, 2009, 2010). As will be illustrated in our case study, this is often not the case in practice. In some PPPs, the cost of using the service may be borne by its users (instead of through general taxation). In others (e.g., private finance initiatives), the private sector partner will provide capital investment with the contractual proviso that the public sector partner be responsible for the cost of providing the service (in whole or in part). There are also mixtures of financial incentives (e.g., capital or revenue subsidies, guaranteed annual revenues, or tax breaks) that are sometimes employed by the public sector as an inducement for private sector investment.

A central justification for the adoption of PPPs is that they are a more efficient way of providing infrastructure or services than those provided by the public sector or through traditional procurement practices. However, it should be noted that many studies have shown that the empirical evidence for such efficiencies is mixed (Flinders, 2005; Loxley \& Loxley, 2010; Whitfield, 2010), with critics pointing out that when "efficiencies" fail there is a tendency to fall back on the public purse.

An unavoidable feature of PPPs is that they introduce a greater degree of complexity to procurement processes. They can vary greatly depending on scope, function, degree of risk-sharing, length of time, instruments used, 


\section{Krawchenko and Stoney (2011)}

and other such variables. A guide produced by the European PPP Expertise Centre describes the complexities of PPPs as requiring "[D]etailed project preparation and planning, proper management of the procurement phase to incentivise competition among bidders. They also require careful contract design to set service standards, allocate risks and reach an acceptable balance between commercial risks and returns" (2011, p. 1).

One feature of this complexity that is often forgotten is how it problematizes open and democratic processes such as transparency, accountability, and public engagement. The confidentiality requirements of PPPs mean that full contract details are not generally made publicly available-which can stifle public debate when the details of contracts may be unknown. We need a balance between confidentiality and accountability. Siemiatycki (2007) presents an excellent overview of this issue and how various governments have addressed it. The longevity of PPP contracts also means that they may outlast many election cycles. Unlike publicly delivered programs and services, PPPs (due to the nature of their contractual obligations) do not open themselves up to debate, particularly at election time, in the way that public services do. How PPPs are accounted for in budgets can also obfuscate their true cost. There is no international accounting standard for the treatment of PPPs and currently no clear and comprehensive rules to provide guidance on this matter (OECD, 2009, p. 91). The wide variation in practices means that governments can use PPPs to bypass normal spending controls. ${ }^{5}$ Akin to problems with transparency of costs, the absence of standards in the cost assessment of PPPs means that they may be perceived as the best "value for money" option in comparison with public sector provision when, in fact, this may not be the case. The Lansdowne Park Partnership, for example, resulted from an unsolicited, sole-sourced bid.

There are no internationally recognized standards for how to structure PPPs versus traditional procurement comparisons-the variables to be considered can often differ greatly. In all, the complexities and long-term nature of PPPs produce information asymmetries that undermine public engagement in and understanding of the proposed project. The degree of complexity inherent to PPPs has been a major impetus for the creation of specialized governmental units or departments to deal with them at the national, provincial/state, and local levels. The inherent complexity of PPPs necessarily requires a different set of expertise than that of traditional procurement contracts. Hence, the pressure to institutionalize PPP practices stems in part from a need for the development of personnel expertise and regulations.

Chart 1 maps the regulatory environment for PPPs. Canada experimented with the use of PPPs in the delivery of infrastructure and services in the 1990s on an ad hoc basis.

The vast majority of acts and regulations in Canada pertaining to PPPs are at the provincial level, which is unsurprising given the provincial authority over municipalities and the prevalence of PPPs provincially, particularly in transportation-related infrastructure projects. British Columbia stands out as having the most acts and regulations for PPP management and being both an early adopter and a province with a dedicated PPP office (Partnerships Canada). Significantly, none of the acts or regulations set standards of practice for community consultation for the specific case of PPPs, which are instead generally seen as a procurement practice and treated as such, with much less emphasis on participation. Community consultation requirements are generally outlined at the level of provincial planning acts (such as the Ontario Planning Act, R.S.O., 1990) or in official and subsidiary plans as a local government level. 


\section{Chart 1: Acts and regulations pertaining to PPPs in Canada}

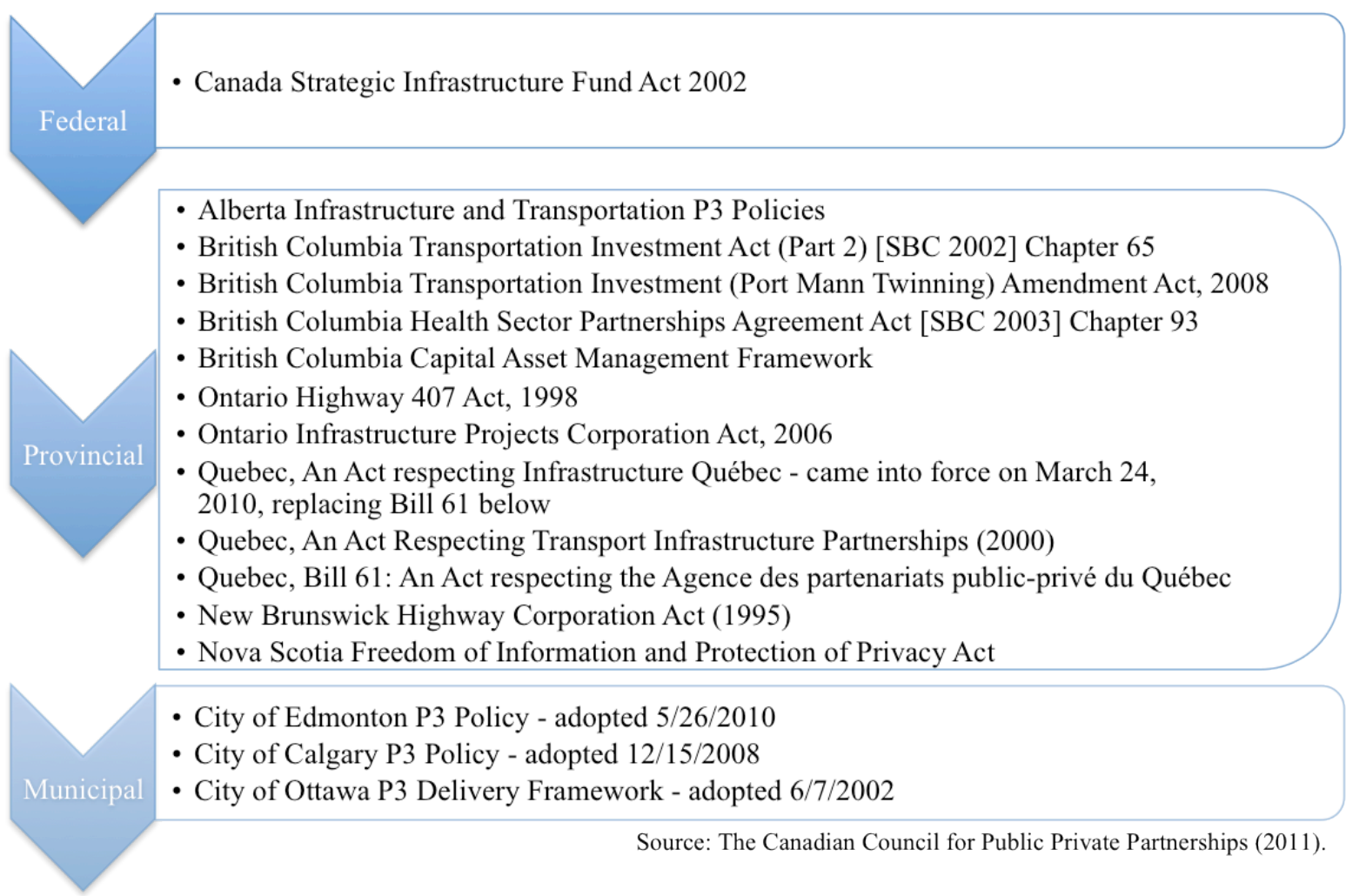

The vast majority of acts and regulations in Canada pertaining to PPPs are at the provincial level, which is unsurprising given the provincial authority over municipalities and the prevalence of PPPs provincially, particularly in transportation-related infrastructure projects. British Columbia stands out as having the most acts and regulations for PPP management and being both an early adopter and a province with a dedicated PPP office (Partnerships Canada). Significantly, none of the acts or regulations set standards of practice for community consultation for the specific case of PPPs, which are instead generally seen as a procurement practice and treated as such, with much less emphasis on participation. Community consultation requirements are generally outlined at the level of provincial planning acts (such as the Ontario Planning Act, R.S.O., 1990) or in official and subsidiary plans as a local government level.

\section{Case study: City of Ottawa Lansdowne Park}

The City of Ottawa is one of the few Canadian cities to have adopted a PPP delivery framework (City of Ottawa, 2002). Its framework document endorses the idea of using PPPs, led to the formation of a Special Delivery Unit within the City Manager's Office for the co-ordination of PPP efforts, and states an increasing desire to engage with PPPs and the need to develop policy and guidelines to further expertise in these dealings. The impetus for increased usage of PPPs is described as stemming from inadequate funding from other levels of government and increasing pressures on the City's budget, where PPPs might "serve as a vehicle for the injection of private sector financing while allowing governments to maintain their fiscal targets and avoid taking on additional debt" (City of Ottawa, 2002, p. 4).

The discussion of "benefits" is followed by a caution that PPPs "are not a substitute for strong and effective governance and decision-making by elected representatives" and that their adoption will require that the City "establish the ground rules and have the ability to shape each P3 to reflect its own objectives, policies and 
regulations [including] ... well-defined contractual remedies in a P3 arrangement that would guarantee the public interest" (City of Ottawa, 2002, pp. 5-6). The document further states the importance of an "open, fair and transparent process" when it comes to the adoption of PPPs and discusses particular drawbacks that stem from the acceptance of unsolicited PPP proposals (City of Ottawa, 2002, p. 5). Because of this, "the City recommends that the $\mathrm{P} 3$ process not be open to unsolicited proposals from the market" (City of Ottawa, 2002, p. 6). Crucially, the Lansdowne partnership breaches these basic recommendations, which were established to promote good governance, ensure value for money, and protect the public interest.

The City of Ottawa opened a PPP Office, housed in the City Manager's Office, in 2002. Between 2002 and 2004, this office initiated five PPPs. In 2004, it was moved from the City Manager's Office to the office of the Planning Department and was re-staffed. During this time, two more PPPs were delivered (the West Carleton Arena and the Orleans Arts Centre and Town Centre). In 2009, a third reorganization moved the PPP Office to the Real Estate Partnerships and Development Branch, which placed it again under the City Manager's Office. This was when the most recent PPP—-the Lansdowne Partnership Plan—was adopted.

The 2002 framework documents recognized the significant dangers of PPPs to the public interest and called for the creation of a PPP policy by 2003. At time of writing it is still in draft form. Meanwhile, the City continues to implement PPPs without recourse to its own guidelines or an established policy. The framework document acknowledges the need for careful thought about and consideration of the adoption of PPPs with special attention to open, transparent, and accountable processes. While many cities in Canada, including the City of Ottawa, have striven to increase community engagement practices in planning as well as in other areas, ${ }^{6}$ they are applied selectively and inconsistently. PPPs require a significant degree of public consultation and community engagement because of the nature of PPP contracts, asymmetries in information, complexity, nature of the risk involved, and need to ensure long-term public accountability and funding for such projects. ${ }^{7}$

\section{Case Study: The Lansdowne Partnership Plan}

Lansdowne Park is a 40-acre historical sport, recreation, and entertainment area located alongside the Rideau Canal, a UNESCO world heritage site, in Central Ottawa. The park is depicted in the photo below.

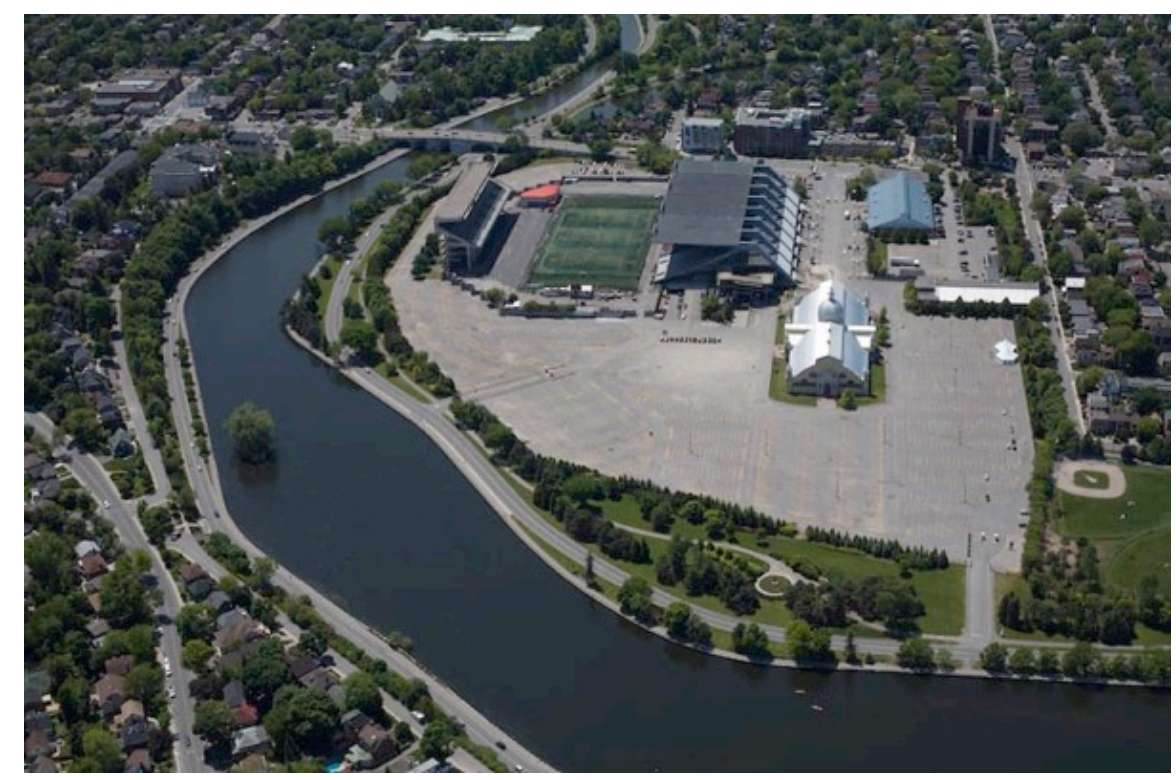

Source: Lansdowne Park Redevelopment (Wikipedia, 2008). 


\section{Krawchenko and Stoney (2011)}

In 2007, cracks were found in the stadium portion of the park (Frank Clair Stadium), prompting the City to begin a redevelopment review of the Lansdowne Park space, including a series of public meetings to provide the framework for any future plans. On October 17, 2008, an unsolicited proposal for the development of a PPP in Lansdowne Park was submitted by the Ottawa Sports and Entertainment Group (OSEG), which includes Jeff Hunt, owner of the Ottawa 67's (a junior hockey team), and Minto Chairman Roger Greenberg. The proposal included the potential signing of a Canadian Football League expansion franchise to be housed in a rejuvenated Frank Clair stadium. OSEG argued that their proposal

represents the best solution for the legacy of Lansdowne: the City of Ottawa will always retain ownership of the park; the residents of Ottawa will have complete access to an innovative new jewel on the Rideau Canal, and the dilapidation on this treasured site will be gone - once and for all. (City of Ottawa 2009, p. 2)

The City subsequently accepted this proposal and abandoned its own plans for the site, which had included a major citizen engagement initiative (Design Lansdowne) that was to establish the criteria for how to proceed to an RFP and an international design competition. The park redevelopment plan has since been modified, with the OSEG proposal to cover the entire park with a mixture of commercial and residential development (condominiums, shopping mall, multiplex cinema, etc.) save for the football stadium and a section near the Rideau Canal which had to be been opened up to a design competition due to public criticism and the insistence of a small group of councillors that their continued support for the project was contingent on it.

As the premier piece of available underdeveloped public space in Ottawa's core, the Lansdowne Park redevelopment has been the subject of heated public debate as well as two citizen-based lawsuits, one of which is still to be heard and another that has been appealed to the Ontario Superior Court. ${ }^{8} \mathrm{~A}$ community-based group called the Friends of Lansdowne (FoL) filed an application with the Ontario Superior Court to stop Ottawa City Council from approving the OSEG-led PPP scheme to redevelop Lansdowne Park. The suit contends that "the City has acted unlawfully by approving the scheme without seeking competitive bids or otherwise complying with City bylaws, and by failing to meet the standard of good faith decision making required of municipal officials" (Friends of Lansdowne, 2011). More specifically, it is argued that under the plan, the City is to provide financial assistance to OSEG, including the leasing of City property at below market value and the subsidization of two sports franchises. The appellants (FoL) contend that in doing so, the City violated section 106 of the Municipal Act, which precludes granting bonuses to commercial entities, and section 270, which requires that municipalities establish and maintain procurement policies.

In addition to the ongoing legal arguments, other criticisms of the plan stem from concerns about the financial impacts on the City, the commercialization of public space, the viability of the sports franchise secured by OSEG, the transportation and environmental impacts, and concerns that the heritage buildings currently housed in the site will not be adequately protected.

In terms of the process, a major criticism of the plan is that details of the PPP, including crucial documents and reports, have not been made available to the public or, in some cases, the City Council. In particular, the court case revealed that the City had not made public its initial evaluation of the project, which had been conducted by the consulting firm Deloitte. The report advised against acceding to OSEG's proposal that the City subsidize OSEG costs to operate two sports franchises (Deloitte, 2009). The Deloitte report represents the only review of the OSEG scheme to have been commissioned by the City and carried out by a competent authority 


\section{Krawchenko and Stoney (2011)}

independent of the City government. Neither the report nor the concerns of its author were shared with the City Council or the public (Friends of Lansdowne, 2011).

Disclosure and transparency are, of course, crucial if the council and the public are to engage in meaningful consideration of the merits of proposals such as this. The complexity and high degree of public interest in the proposed deal raise vital questions about the costs of the PPP to taxpayers, the burden of risks between public and private actors, and the rational for the PPP's adoption (e.g., why this was chosen without any cost comparisons with other procurement types).

The FoL case presented affidavits by Rosen and Associates (a leading investigative accounting firm) and Professor Harry Kitchen (a leading expert on Canadian municipal finance) which both found that the City grossly misrepresented the financial impacts of the PPP. Access to the reports, facts, and information requested for the court challenge by FoL has been a long and expensive process that most community-based groups would be unable to sustain. ${ }^{9}$ The lack of transparency throughout the PPP process by the City has been a major obstacle to accountability, transparency, and citizen engagement. Informed debate and participation have been greatly hampered by a lack of detailed documentation and communication from the City.

The major pieces of public consultation for the Lansdowne PPP are outlined in the chart below and include: 1) zoning consultation, 2) public consultation, and 3) design consultation on the "non-developer"-led portion of the land. While these lay out some basic requirements for engaging citizens in the process, their impact has been severely limited by a number of factors, including limited information on the project and the late timing of the consultation within the development process.

\section{Chart 2: City of Ottawa: Lansdowne public consultation phases}
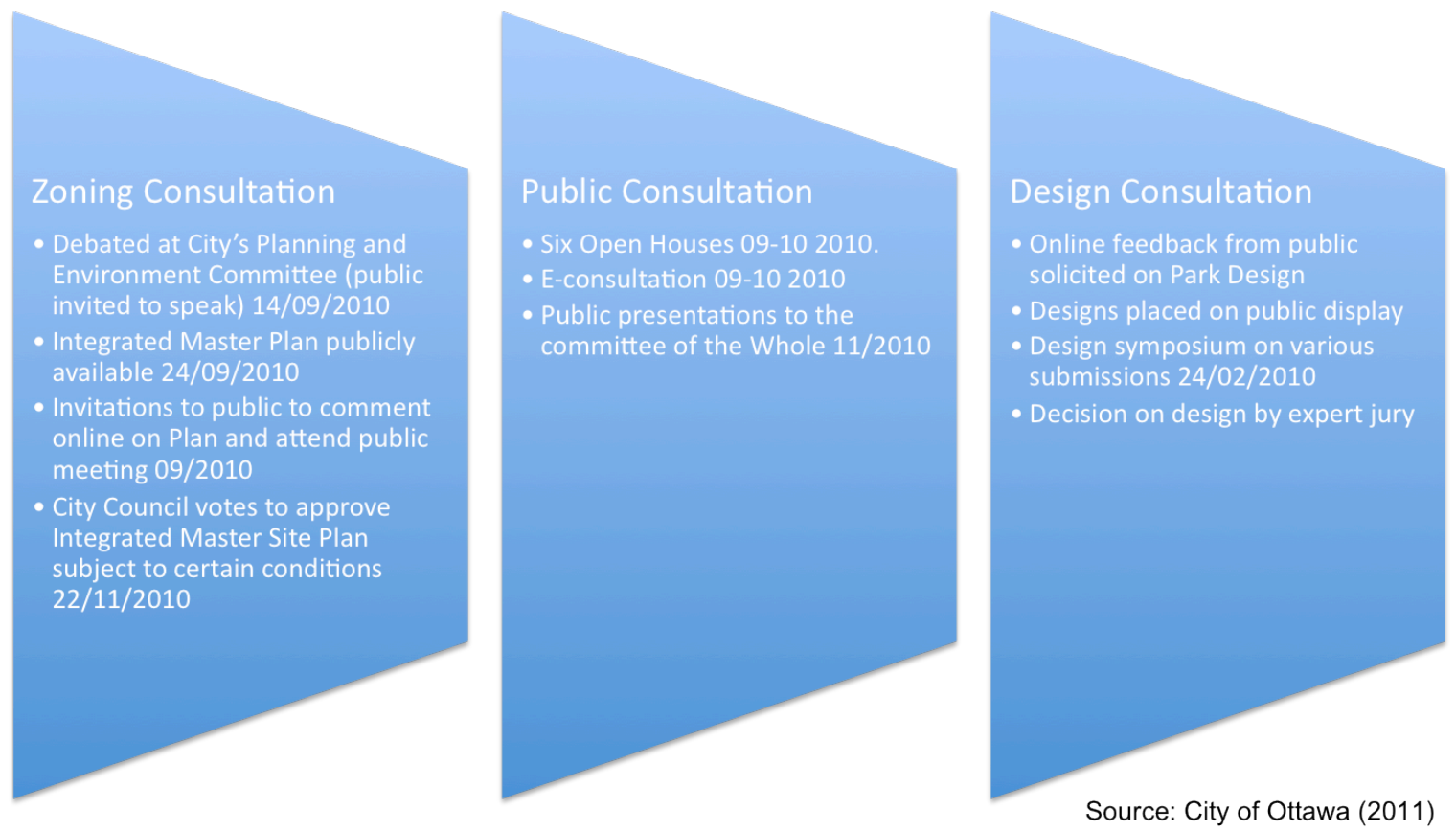

Substantive and early public consultation was initially undermined by the decision to adopt an unsolicited and sole-sourced bid, allowing little or no possibility for the public to participate in and shape a vision for the park. 
The lack of a competitive process denies the public a chance to see, hear, and debate what is possible in addition to assessing the costs and benefits of alternative proposals.

\section{Chart 3: Outcome of consultation strategies}

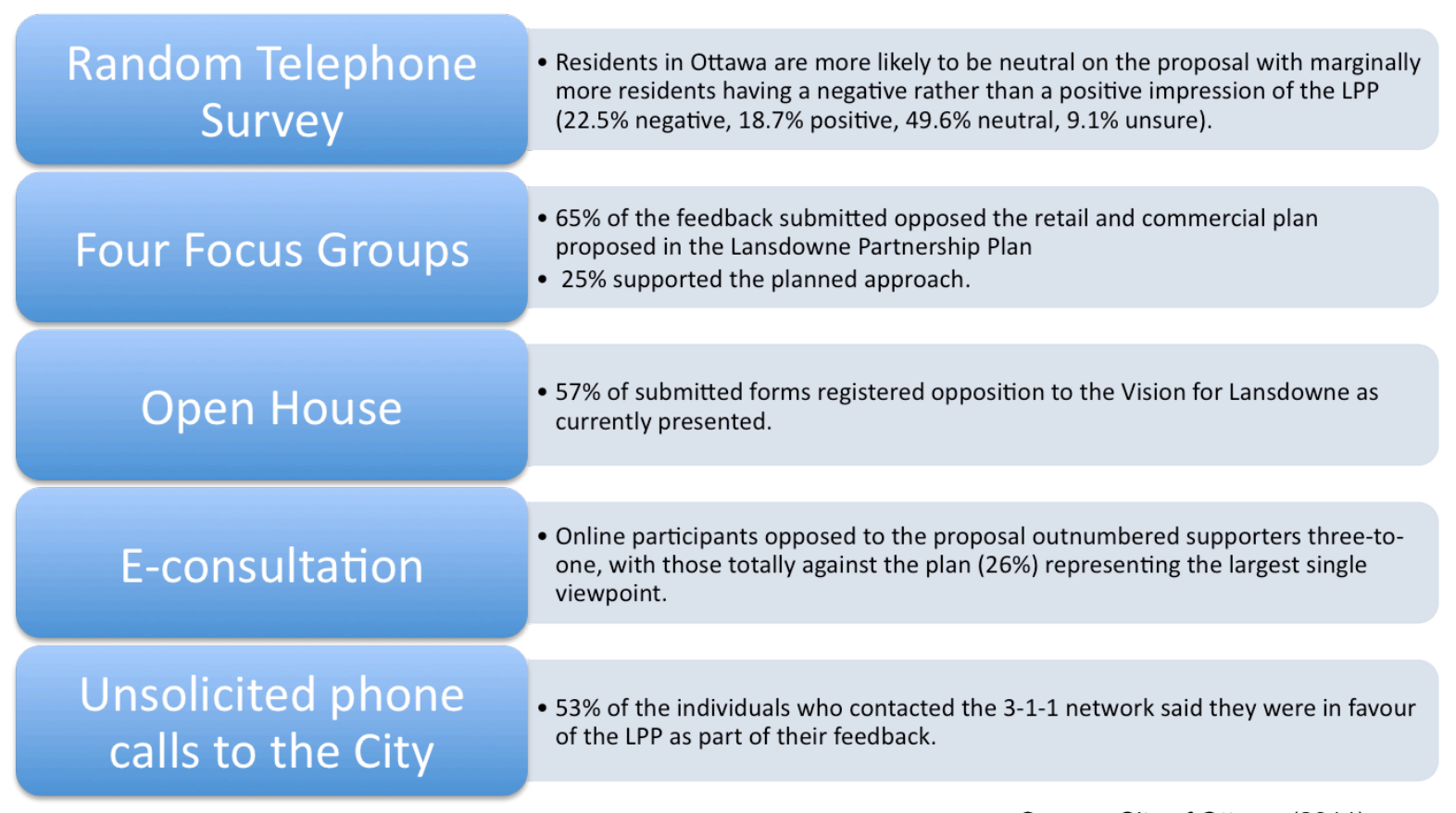

Source: City of Ottawa (2011).

The analysis of the public consultation feedback shows that many residents voiced concerns about various aspects of the proposal. It is not evident how, or even if, this information has been incorporated into the planning process. Public meetings organized by the City appeared to be staged and controlled. At one of the open houses used to present the plan to the residents of the Glebe and Ottawa South (where Lansdowne Park is situated and where the community will be most affected), no questions about the process were allowed, no elected officials were available to answer questions (except for the area councillor who strongly opposes the plan), and members of the OSEG team were misleadingly identified on their name tags as City of Ottawa officials. This further blurred the lines between the developers and City staff who are responsible for providing accurate and unbiased information to the public.

Partly as a consequence of the lack of transparency, the cost of the PPP for the City remains unclear. Several details have emerged as a result of the court case and the accompanying added scrutiny. The official Lansdowne cost is estimated at $\$ 129$ million, the majority of which will be borrowed for repayment over 40 years, bringing the total cost to $\$ 285$ million in repayments. The plan does not have funding commitments from senior levels of government whose involvement in the project was negated by the sole-sourced nature of the agreement. The private sector partner (OSEG) is a major beneficiary of this agreement-for one dollar a year, they will lease 10 acres of Lansdowne's prime land on which they will build commercial and residential amenities. Further, the private developer (OSEG) will be awarded a 30-50 year contract for the management of the park, for which the fees are currently unknown. Full knowledge and transparency of costs, as well as comparative options, are a crucial component of public engagement. Without this information, public engagement cannot proceed with any meaning. A major focus of the citizen-based lawsuit involved obtaining access to the documents that outline such details. 


\section{Krawchenko and Stoney (2011)}

On July 28, 2011, Justice Hackland's decision for the Lansdowne challenge at the Ontario Superior Court found in favour of the City of Ottawa. A major focus of the court case was whether the City of Ottawa had acted in bad faith by accepting a sole-source bid. Justice Hackland's decision states, "this court has no jurisdiction to pass on the wisdom or the reasonableness of these policy decisions, and to the limited extent that the court may intervene, a generous deferential standard of review is required" (Hackland, 2011, p. 6). In this, the judgment "extends substantial deference to the decisions of municipal councils" (Hackland, p. 5). This decision is presently being appealed through the Ontario Court of Appeal. The Lansdowne Park Conservancy (a group of Ottawa business owners) is also bringing forward a legal review through the Ontario Divisional Court against the City of Ottawa to request that the PPP be opened to a competitive bidding process. The legal challenges against the Lansdowne PPP continue.

\section{DISCUSSION AND CONCLUSIONS}

The Lansdowne case study epitomizes the conflicting motives and interests between private and public sector interests and concerns. Whereas the private sector focus will necessarily be on profit, risk minimization, and timeliness, those responsible for guarding the public interest are charged with ensuring due process, effective representation, and good governance practices in addition to value for money. This will inevitably create tension between the parties about the pace, openness, transparency, and inclusiveness of the process and generate pressures to compromise the public interest to accommodate private interests. In the case of Lansdowne Park, this was evident when the City's open and inclusive "design Lansdowne" process was cancelled in favour of an unsolicited proposal by local developers after they had indicated that they would not be prepared to take part in a competitive process.

As with many other cases of land use planning, the Lansdowne case illustrates that attempts to short-cut or bypass due process and limit public engagement to "manipulative" or "therapeutic" forms of engagement may actually prolong rather than expedite the PPP process (Arnstein, 1969). The ongoing legal challenges that continue to delay development of the Lansdowne Park appear to provide further support for the adage that "the longest way round is the shortest route home." Avoiding or reducing public opposition through early public engagement in an informed and transparent process is important for a number of reasons related both to the timeliness and efficiency of the project as well as its legitimacy and acceptability. Both measures are crucial to the concept and practice of good governance. Rather than conceiving them as two mutually exclusive aims, they should be seen as co-dependent requirements for an efficient and effective process that engages the public, builds trust, and manages political interests and expectations.

Public opposition to PPPs and the projects they undertake increases the uncertainty and risk and can ultimately undermine a project's development (OECD, 2009, p. 118). Although transparency and due process, including substantive public engagement, may appear cumbersome and counterintuitive to private sector representatives-and even to many public officials-involved in the PPP process, they are very significant in reassuring the public that the public interest is being served and in allaying concerns that nefarious or unethical practices are being pursued under the veil of commercial confidentiality and secrecy.

In this context, a 2009 OECD policy document outlines five areas of concern related to corrupt and unethical behaviour in PPP procurement practices. These include: 1) information asymmetry where the discretionary power of a public purchasing agent or a private bidder possesses information not available to the government; 2) contacts, informal networks, and collusion can be abused to influence the bidding process; 3) conflict of interest with public officials; and 4) political financing where politicians may use their influence to sway bidding outcomes favourable to their political interests (OECD, 2009, pp. 122-123). Although the public's understanding of "corruption" is often limited to such obvious forms as the "exchange of brown envelopes," it is important to note that it is a much broader concept and can include one or more of the above activities. It is within this broader definition of corruption that PPPs become vulnerable, meaning that extra care must be taken to ensure 


\section{Krawchenko and Stoney (2011)}

that public confidence is maintained, especially when the PPP is dealing with a project such as Lansdowne which is enormously complex and significant to the public and local community.

To this end, municipal staff must remain independent from private partner interests, however difficult this is given that PPPs require them to work closely together. PPPs also introduce the potential to blur the lines between the role of councillors in promoting the public interest, and the developers whose legitimate role it is to further their own private interests. Several councillors in the Lansdowne case have been prominent and vocal advocates of the OSEG proposal, both at council meetings and through the media. Their unrelenting promotion of the project allied to their public denigration of citizens and groups who object to the proposal on a variety of grounds epitomizes "boosterism."10 To be clear, the role of councillors is to represent public, not private, interests but this important distinction appears to have been dangerously compromised with respect to the Lansdowne Partnership Plan. Concern about the blurring of roles and responsibilities is exacerbated by the fact that many of the councillors who promoted the Lansdowne deal received political campaign funding from the same developers they were expected to regulate (Ecology Ottawa, 2009). ${ }^{11}$ While this is certainly not illegal under current municipal rules, the optics are disturbing and reinforce recent calls to strengthen and update the "ethical infrastructure" of local government (Cunningham, 2011).

The Lansdowne case leads us to conclude that robust community engagement practices need to be institutionalized as part of the regulations guiding PPP procurement practices-practices of accountability, transparency, and public engagement should, if anything, be heightened in the adoption of PPPs due to issues of moral hazard and information asymmetries.

Of course, not all PPPs will require the same degree of transparency and public participation to be legitimate. In highlighting the redevelopment of Lansdowne Park, we did not intend to make a case against the use of PPPs generally. Indeed, we believe that, done correctly and with appropriate respect for due process, they can provide a very effective tool for delivering public services and projects. However, in the process of producing this article we have developed a potentially helpful and informative framework that can, and perhaps should, be used by policymakers considering a PPP and by researchers attempting to identify the conditions or types of regimes associated with effective and legitimate partnerships. Specifically, we propose that in certain circumstances PPPs are inappropriate and should not be used.12

\section{Chart 4: Conditions in which PPPs are inappropriate}

\begin{tabular}{|l|l|}
\hline Conditions inappropriate for PPPs & Rationale \\
\hline $\begin{array}{l}\text { Proposed use of public space is highly } \\
\text { controversial. }\end{array}$ & $\begin{array}{l}\text { Highly political or contested land use decisions need to } \\
\text { be dealt with in an open and transparent way that } \\
\text { PPPs may not be able to facilitate. }\end{array}$ \\
\hline Involves an unsolicited bid. & $\begin{array}{l}\text { Unsolicited proposals preclude early input from the } \\
\text { public or community about what the key requirements } \\
\text { of the project or service are. }\end{array}$ \\
\hline Procurement method is sole-sourced. & $\begin{array}{l}\text { Competitive procurement helps to establish best or fair } \\
\text { market values and also generate public debate and } \\
\text { ideas. }\end{array}$ \\
\hline $\begin{array}{l}\text { Councillors funded by the private } \\
\text { partner(s) in the proposed PPP. }\end{array}$ & $\begin{array}{l}\text { Councillors need to be at arm's length and independent } \\
\text { from private sector partners if they are to perform their } \\
\text { role in promoting the public interest effectively and } \\
\text { holding PPPs to account. }\end{array}$ \\
\hline
\end{tabular}




\title{
Krawchenko and Stoney (2011)
}

Any one of these conditions might be sufficient to render a PPP an inappropriate and ineffective policy option; and yet, the Lansdowne Park Partnership is being pursued even though all four conditions apply. Given the context, history, and significance of Lansdowne Park and its impact on local communities, any process used to plan its future (redevelopment) legitimately and effectively requires more, not less, transparency to facilitate public scrutiny, participation, and accountability. Failure to respect this may explain why many citizens remain suspicious of the Lansdowne process and why the project remains bogged down in legal challenges and delays almost four years on. Indeed, the Asian Development Bank's handbook on PPPs provides a clear and prescient warning to public officials that entering into sole-sourced PPPs carries elevated risks of corruption and delay:

\begin{abstract}
Entering into a sole-source process can save government time and money and may alert government to an unrealized opportunity for PPP. However, sole sourcing can encourage corruption through lack of transparency, and the cost benefits to competitive bidding are lost ... there is also an elevated risk that the fairness of the contract award will be challenged at a later stage, e.g., by disappointed potential bidders or by the political opposition. (Asian Development Bank, 2008, 72)
\end{abstract}

FoL is reviewing several of the legal aspects raised by the case; but if the legal challenges to the Lansdowne Park Partnership are unsuccessful, we must hope that the City of Ottawa will not regard the decision as a charter to conduct PPPs in the way it has at Lansdowne Park. Whatever the outcome, the City requires a clear policy on how it approaches PPPs and this should build on many of the laudable aspirations set out in its framework document discussed earlier. In addition to the financial costs and the time spent trying to resolve the City of Ottawa's PPP-led development of Lansdowne Park, the divisions, suspicion, ill will, and hostility generated by the project may have long-lasting implications for how PPPs are formed in the future. Unfortunately, its legacy may be to undermine public trust and confidence in the process and make it more difficult to implement PPPs in the future.

PPPs are being increasingly adopted and institutionalized across Canada. We hope this article will contribute to some broader debates about the future direction of PPPs and indicate promising areas for research that will allow the economic potential of PPPs to be reconciled with the social and political dimensions in these practices. To this end, the emergence of Public Private Community Partnership (PPCP) models may offer a way to better address these latter dimensions and, in doing, help to realize the putative economic and financial benefits of PPP development. At the moment PPCP models are most commonly used in developing countries as a means to reorient partnerships toward social welfare goals and away from a narrow profit-based model (see Alam, 2008). This type of procurement model has had very little traction in Canada to date. However, given the limitations of PPPs and the inherent trade-offs between public engagement and corporate confidentiality highlighted in this article, PPCPs offer an important and timely area of practice and research.

The Lansdowne Park case study raises and addresses some fundamental questions about the future role of local government in Canada and beyond. As Tindal and Tindal ask, which path will municipalities choose?

They can continue along the path of least resistance, the one that accepts the inevitability of global economic forces, neoliberalism, and a diminished role for all governments. Or they can recommit to their political role - engaging local citizens more fully, asserting themselves more forcefully, and collaborating more widely in 


\section{Krawchenko and Stoney (2011)}

pursuit of the local public interest. The second path is uphill, but it leads somewhere, unlike the first. (Tindal \& Tindal, 2009, p. 1)

Viewed in this context, Lansdowne Park could set an ominous precedent for municipalities and local citizens alike.

\section{ACKNOWLEDGMENTS}

We would like to thank our anonymous reviewers and the journal editor for their guidance in preparing and improving this article. We would also like to thank the School of Public Policy and Administration at Carleton University for providing T. Krawchenko with the funding to attend the 2011 ANSER conference where an earlier draft of this article was presented.

\section{NOTES}

1. For example, the federal government's Building Canada Fund for economic stimulus included a stipulation that for any project receiving $\$ 50$ million or more, a PPP delivery option must be fully considered.

2. Alberta (through the Alberta Treasury Board), British Columbia (through Partnerships BC), New Brunswick (through the Department of Supply and Services and New Brunswick Department of Transportation), Nova Scotia (through Strategic Infrastructure Partnerships), Ontario (through Infrastructure Ontario), and Quebec (through Infrastructure Quebec and Transport Quebec).

3. Value-for-money assessments are either based on a cost benefit analysis of all alternative provision methods available (public and private) or the calculation of a public sector comparator either before or after the PPP bidding process. Some countries (e.g., France) use no public or private comparator (OECD, 2010, p. 24).

4. Interviews were also conducted with officials from the City of Ottawa on this matter. However, due to the legal challenge being presented by this case, these interviews were non-attributable and cannot be referenced here.

5. PPPs have been used to move expenditures to future budgets, thereby increasing public sector liabilities that are borne by future taxpayers who inherit the costs of "buy now, pay later" policies. In Canada, this has been done in the past through off-book financing where PPPs were structured as operating leases (costs as incurred) as opposed to capital leases (costs as financial liability). The decision to structure the PPP as a capital or operating lease is typically dependent upon the degree of public versus private sector risk shared by the partners. In the case of a capital lease, the public sector partner would bear more of the risk. As of January 1, 2009, municipal governments in Ontario are required by law to adopt full accrual accounting methods. This should address the problems with transparency inherent to the cash-based operational lease method of accounting for PPPs. However, "there are still questions about how governments should record P3 payments-because the capital and operating costs in a P3 are combined into a unitary payment it can be difficult to assign a cost to the capital asset" (Fussell \& Beresford, 2009, p. 28).

6. See, for example, the City's Neighbourhood Planning Initiative (NPI) and the Community Development Framework (CDF).

7. We note here that the sole-sourced nature of the Lansdowne partnership effectively excludes the federal or Ontario provincial governments from funding the project given their own procurement protocols.

8. At the initial hearing, the judge ruled for the City on the grounds that it was not for the courts to overturn the political decisions of elected bodies. Justice Hackland also felt that the FoL case failed to show that the City had broken the Municipal Act by entering into "bonusing," broken City by-laws by entering into a sole-sourced arrangement without seeking competitive bids, or had intentionally acted in "bad faith." The decision has been appealed, but although the lawfulness of the City's actions is obviously an important matter it does not affect the analysis and arguments being made in this article. Our focus is on the implications of PPPs for "good" governance and we do not make any claims or judgments about their lawfulness or otherwise in this article.

9. To date FoL has raised almost $\$ 300,000$ to fund their legal challenge.

10. Lightbody defines "boosterism" as "the activities of those whose unbridled support for a community's sustained growth is assessed solely by commercial measures. For these people, the role of local government is to support expansion by the community's entrepreneurs at the expense of any and all other objectives (social, cultural, environmental)," (2006, p. 545). 


\section{Krawchenko and Stoney (2011)}

11. A report by Ecology Ottawa showed that all but six City of Ottawa councillors accepted campaign contributions from developers in the 2006 election.

12. If PPPs are to be used in such circumstances then we would obviously argue that a rigorous process of public scrutiny and participation is essential.

\section{REFERENCES / BIBLIOGRAPHIE}

Acar, M., Chao G., \& Kaifeng Y. (2008). Accountability when hierarchical authority is absent. The American Review of Public Administration, 38(1), 3-23.

Alam, K. (2008). An economic analysis of the Public Private Community Partnership model: The case of solid waste management. Proceedings of the 37th Australian Conference of Economists, The Economic Society of Australia, September 4, 2008.

Arnstein, S., (1969). A ladder of citizen participation. Journal of the American Institute of Planners, 35, 216-24.

Asian Development Bank. (2008). Public Private Partnerships (PPP) Handbook. URL: http://www.adb.org /Documents/Handbooks/ Public-Private-Partnership/Chapter7.pdf [October 11, 2011].

Bardach, E. (2003). Policy analysis and public participation. Journal of Policy Analysis and Management, 22(1), 115-117.

Bel, G., \& Warner, M.E. (2008). Challenging issues in local privatization. Environment and Planning C: Government and Policy, 26(1), 104-109.

Boyne, G.A. (1998). Public service under New Labour: Back to bureaucracy? Public Money and Management, 18(3), 43-50.

Box, R.C. (1999). Running government like a business: Implications for public administration theory and practice. American Review of Public Administration, 29, 19-43.

Bradford, N. (2003). Public-private partnership? Shifting paradigms of economic governance in Ontario. Canadian Journal of Political Science/Revue canadienne de science politique, 36(5), 1005-1033.

Brinkerhoff, D.W., \& Brinkerhoff, J.M. (2011). Public-private partnerships: Perspectives on purposes, publicness, and good governance. Public Administration and Development, 31(1), 2-14.

City of Ottawa. (2002). City of Ottawa PPP Framework Policy. Approved by City Council on June 26, 2002. Ottawa, ON: City of Ottawa.

City of Ottawa. (2009). Lansdowne Partnership Plan. Presented to City Council September 2, 2009. URL: http://www.ottawa.ca /residents/public_consult/lansdowne_partnership/sept02_report_en.pdf [April 30, 2011].

Cunningham, Justice, The Honourable J.D. (2011). Updating the ethical infrastructure: Report on the Mississauga judicial inquiry. October 3, 2011.

Deloitte. (2009). Review of the Lansdowne Live proposal. City of Ottawa, March 2009. URL: http://www.letsgetitright.ca/images/legal Ideloitte-report.pdf [September 10, 2011].

Ecology Ottawa. (2009). Do developers run City Hall? A report examining 2006 municipal election campaign contributions from developers to Ottawa city councillors and the mayor. Ottawa, ON: Ecology Ottawa.

Eggers, W.D., \& O'Leary, J. (1995). Revolution at the roots: Making our government smaller, better, and closer to home. New York, NY: Free Press.

Elkin, S. L. (1987). City and regime in the American republic. Chicago, IL: University of Chicago Press. 


\section{Krawchenko and Stoney (2011)}

Entwistle, T., \& Martin, S. (2005). From competition to collaboration in public service delivery: A new agenda for research. Public Administration, 83(1), 233-242.

European PPP Expertise Centre. (2011). A Guide to Guidance: Sourcebook for PPPs. Version 2, February 2011. Luxembourg: European Investment Bank.

Flinders, M. (2005). The politics of public private partnerships. British Journal of Politics and International Relations, 7, 215-239.

Forrer, J., Kee, J., Newcomer, K., \& Boyer, E. (2010). Public-private partnerships and the public accountability question. Public Administration Review (Washington, DC), 70(3), 475-484.

Friends of Lansdowne. (2011). Factum of the Appellant. URL: http://www.letsgetitright.ca/ [October 6, 2011].

Fussell, H., \& Beresford, C. (2009). Public private partnerships: Understanding the challenge, second edition. Vancouver, BC: Centre for Civic Governance: Columbia Institute.

Graham, K.A., \& Philips, S.D. (2008). Citizen engagement: Beyond the customer revolution. Canadian Public Administration, 40(2), 255-273.

Hackworth J. (2007). The neoliberal city: Governance, ideology, and development in American urbanism. Ithaca, NY: Cornell University Press.

Hackland, R.S.J. [Justice]. (2011). Legal decision in Friends of Lansdowne versus the City of Ottawa. Ontario Superior Court of Justice, court file no. 10-49352, July 28, 2011. Ottawa, ON: City of Ottawa.

Harvey, D. (1989). From managerialism to entrepreneurialism: The transformation of urban governance in late capitalism. Geografiska Annaler, $71,3-17$.

Hood, C.C. (1995). The "New Public Management" in the 1980s: Variations on a theme. Accounting, Organisations and Society, 20(2/3), 93-109.

Ilcan, S. (2009). Privatizing responsibility: Public sector reform under neoliberal government. Canadian Review of Sociology, 46(3), 207-234.

Johnston, J., \& Gudergan, S. (2007). Governance of public-private partnerships: Lessons learnt from an Australian case? International Review of Administrative Sciences, 73(4), 569-582.

Leitner, H. (1990). In pursuit of economic growth: The local state as entrepreneur. Political Geography Quarterly, 9, 146-170.

Lightbody, J. (2006). City politics: Canada. Toronto, ON: University of Toronto Press.

Loxley, J., \& Loxley, S. (2010). Public service, private profits: The political economy of public-private partnerships in Canada. Black Point, NS: Fernwood Publishing.

Macário, R. (2010). Critical issues in the design of contractual relations for transport infrastructure development. Research in Transportation Economics, 30(1), 1-5.

Miraftab, F. (2004). Public-private partnerships. Journal of Planning Education and Research, 24(1), 89-101.

OECD. (2009). Public Private Partnerships: In pursuit of Risk Sharing and Value for Money. Paris: OECD Publishing.

OECD. (2010). Dedicated Public Private Partnership Units: A survey of institutional and governance structures. Paris: OECD Publishing.

Ortiz, I., \& Buxbaum, J. (2008). Protecting the public interest in long-term concession agreements for transportation infrastructure. Public Works Management \& Policy, 13(2), 126-137. 


\section{Krawchenko and Stoney (2011)}

Plunkett, T.J. \& Betts, G.M. (1978). The management of Canadian urban government. Kingston, ON: Queen's University.

Savas, E.S. (2000). Privatization and public-private partnerships. New York, NY: Chatham House.

Siemiatycki, M. (2007). What's the secret? Journal of the American Planning Association, 73(4), 388-403.

Siemiatycki, M. (2010). Delivering transportation infrastructure through public-private partnerships: Planning concerns. Journal of the American Planning Association, 76(1), 43-58.

Stone, C. N. (1989). Regime politics: Governing Atlanta, 1946-1988. Lawrence, KS: University of Kansas Press.

Tindal C.R., \& Tindal, S. (2009). Local government in Canada, seventh edition. Toronto, ON: Nelson.

Wallner, J. (2008). Legitimacy and public policy: Seeing beyond effectiveness, efficiency, and performance. Policy Studies Journal, $36(3), 421-443$.

Warner, M.E., \& Hefetz, A. (2004). Pragmatism over politics: Alternative service delivery in local government, 1992-2002. In Washington DC, The Municipal Yearbook 2004, (pp. 8-16). Washington, DC: International City/County Management Association.

Whitfield, D. (2010). Global auction of public assets: Public sector alternatives to the infrastructure market and public private partnerships. Nottingham, UK: Spokesman Books.

Wikipedia. (2008). Landsdowne Park redevelopment. URL: http://en.wikipedia.org/wiki/Lansdowne Park redevelopment [September 10, 2011].

\section{About the authors / Les auteurs}

Tamara Krawchenko is a PhD Candidate, School of Public Policy and Administration, Carleton University. Email: tkrawche@connect.carleton.ca

Christopher Stoney is Associate Professor, School of Public Policy and Administration, Carleton University. Email: cstoney@connect.carleton.ca 